\title{
Production of a cloned calf from a fetal fibroblast cell line
}

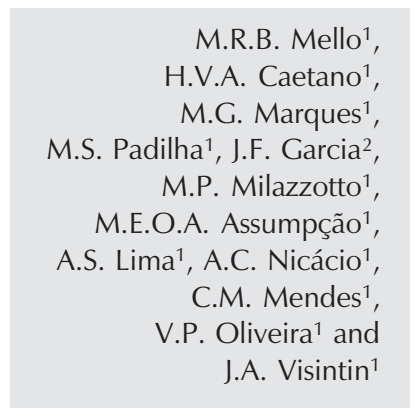

\author{
1Departamento de Reprodução Animal, Faculdade de Medicina Veterinária, \\ Universidade de São Paulo, São Paulo, SP, Brasil \\ ${ }^{2}$ Departamento de Saúde Animal e Produção, Universidade de São Paulo, \\ Araçatuba, SP, Brasil
}

\author{
Correspondence \\ M.R.B. Mello \\ Departamento de Reprodução Animal \\ Faculdade de Medicina Veterinária \\ Universidade de São Paulo \\ R. Prof. Orlando M. de Paiva, 87 \\ 05508-000 São Paulo, SP \\ Brasil \\ Fax: +55-11-3091-7412 \\ E-mail: mrbmello@usp.br
}

Research supported by FAPESP

(No. 99/07377-3) and CNPq.

Received August 29, 2002

Accepted July 10, 2003

\begin{abstract}
The present study examined the in vitro and in vivo development of bovine nuclear-transferred embryos. A bovine fetal fibroblast culture was established and used as nucleus donor. Slaughterhouse oocytes were matured in vitro for $18 \mathrm{~h}$ before enucleation. Enucleated oocytes were fused with fetal fibroblasts with an electric stimulus and treated with cytochalasin D and cycloheximide for $1 \mathrm{~h}$ followed by cycloheximide alone for $4 \mathrm{~h}$. Reconstructed embryos were cultured for 7-9 days and those which developed to blastocysts were transferred to recipient cows. Of 191 enucleated oocytes, 83 (43.5\%) were successfully fused and $24(28.9 \%)$ developed to blastocysts. Eighteen freshly cloned blastocysts were transferred to 14 recipients, 5 (27.8\%) of which were pregnant on day 35 and $3(16.7 \%)$ on day 90 . Of the three cows that reached the third trimester, one recipient died of hydrallantois 2 months before term, one aborted fetus was recovered at 8 months of gestation, and one delivered by cesarian section a healthy cloned calf. Today, the cloned calf is 15 months old and presents normal body development $(378 \mathrm{~kg}$ ) and sexual behavior (libido and semen characteristics).
\end{abstract}

Embryo reconstruction by transfer of a donor nucleus to an enucleated oocyte was first proposed by Spemann in 1938 (1) using a two-cell salamander embryo. Briggs and King in 1952 (2) demonstrated that in Leopard frogs (Rana pipiens) certain nuclei could direct development to a sexually mature adult. These experiments used embryonic blastomeres as nucleus donors because they were
Key words - Cloning

- Nuclear transfer

- Bovine

- Fetal fibroblasts

- Embryo reconstruction thought to be undifferentiated and consequently ready to be reprogrammed (3).

Recently, the development of somatic cell nuclear transfer has become more successful in producing cloned animals (4-8). The ability to produce cloned offspring from a cell population that can be maintained in culture offers numerous advantages in the fields of research, agriculture and biotechnology (8). 
Propagation in culture provides many millions of cells that can be used either to produce large numbers of identical offspring or for genetic modification and production of transgenic animals (9). Uhm et al. (10) demonstrated expression of enhanced green fluorescent protein (EGFP) gene in porcine embryos following nuclear transfer. Pregnancies have been reported in cattle after the transfer of cloned embryos derived from serum-starved fetal fibroblasts (11) or muscle and skin fibroblast cells (12).

Therefore, the aim of the present study was to examine the in vitro and in vivo development of transferred bovine nuclear embryos reconstructed with serum-starved fetal fibroblasts.

\section{Establishment of a fetal fibroblast cell line}

A 45-day-old male bovine fetus was obtained from a slaughterhouse and transported to the laboratory in saline solution at $30^{\circ} \mathrm{C}$. After washing with Dulbecco's phosphatebuffered saline (DPBS), the head and internal organs were removed and the remaining tissue was cut into small pieces with scissors. Tissue pieces were rinsed twice in DPBS and seeded in flask containing Dulbecco's modified Eagle's medium (DMEM) supplemented with $10 \%$ fetal calf serum (FCS) and $50 \mu \mathrm{g} / \mathrm{ml}$ gentamicin for $24 \mathrm{~h}$. Next, the flasks were rinsed with DPBS in order to remove the pieces of tissue and the remaining attached fibroblasts were cultured until reaching confluence (1 week). After confluence, fibroblast cells were harvested using $0.05 \%$ trypsin and $0.5 \mathrm{mM}$ EDTA solution. Part of the cells were reseeded onto $60-\mathrm{mm}$ tissue culture plates and the remaining cells were frozen in DMEM with 20\% FCS and $10 \%$ dimethylsulfoxide.

\section{Oocyte maturation}

Ovaries were obtained from a slaughterhouse and maintained at $30^{\circ} \mathrm{C}$ during trans- port to the laboratory. Cumulus oocyte complexes (COCs) were aspirated from follicles measuring 2-8 $\mathrm{mm}$ in diameter using a syringe with a $21-\mathrm{G}$ needle. COCs were assessed morphologically and only oocytes that showed compact cumulus cells and homogeneous ooplasm were selected for in vitro maturation. The COCs were matured for 16$18 \mathrm{~h}$ in TCM199 plus 10\% FCS supplemented with $0.5 \mu \mathrm{g} / \mathrm{ml}$ FSH (Folltropin; Vetrepharm, Belleville, Ontario, Canada), $50 \mu \mathrm{g} / \mathrm{ml} \mathrm{LH}$ (Chorulon; Intervet, Boxmeer, Holland), $1 \mu \mathrm{g} / \mathrm{ml}$ estradiol (Sigma, St. Louis, MO, USA), $22 \mu \mathrm{g} / \mathrm{ml}$ pyruvate, and $50 \mu \mathrm{g} / \mathrm{ml}$ gentamicin. After the maturation period, $\mathrm{cu}-$ mulus cells were totally removed by incubating $\mathrm{COCs}$ in $0.1 \%$ hyaluronidase solution for $10 \mathrm{~min}$ and by gentle pipetting with a stripping pipette of the same diameter as the oocytes.

\section{Oocyte enucleation}

The micromanipulation medium used was DPBS $+20 \%$ FCS. After fitting the micromanipulators (Narishige, Tokyo, Japan) with the holding and enucleating pipette, cumulus-free oocytes with the first polar body were selected for enucleation. This procedure was carried out by cutting the zona pellucida close to the first polar body using a glass needle and pushing out by compression a very small amount of cytoplasm beneath the polar body. Successful enucleation was confirmed by visualizing the karyoplast that had been pushed out and stained with $5 \mu \mathrm{g} / \mathrm{ml}$ Hoechst 33342 (St. Louis, MO, USA) under ultraviolet light. In this way, the recipient oocytes were not exposed to ultraviolet light.

\section{Fibroblast preparation}

The fibroblasts used as nuclear donors were synchronized at presumptive G0/G1 by serum starvation. Two to three days before nuclear transfer, the culture medium was replaced with fresh medium containing $0.5 \%$ 
FCS (serum starvation). Thirty minutes before nuclear transfer, a cell suspension of fetal fibroblasts was prepared by standard trypsinization.

\section{Nuclear transfer and activation}

The medium used was the same as that employed for enucleation (DPBS + 20\% FCS). An individual fibroblast was introduced into an enucleated oocyte through a slit in the zona pellucida (Figure 1A) and the enucleated oocyte-nucleus donor cell complexes were transferred to the fusion medium ( $0.3 \mathrm{M}$ mannitol). After $5 \mathrm{~min}$, the complexes were aligned in the electrode chamber and fused and activated with one DC pulse of $4.0 \mathrm{kV} / \mathrm{cm}$ for $20 \mu \mathrm{s}$. After fusion, reconstructed embryos were chemically activated with cytochalasin $\mathrm{D}(2.5$ $\mu \mathrm{g} / \mathrm{ml})$ and cycloheximide $(10 \mu \mathrm{g} / \mathrm{ml})$ for $1 \mathrm{~h}$ and cycloheximide alone for a further $4 \mathrm{~h}$. The fusion rate was determined $1 \mathrm{~h}$ after electrofusion by microscopic examination before in vitro culture.

\section{In vitro culture}

Nuclear-transferred embryos were cocultured with a granulosa cell layer in a 50$\mu \mathrm{l}$ drop of tissue culture medium $199+10 \%$ FCS overlaid with mineral oil. Embryos were cultured in an incubator chamber at $38.5^{\circ} \mathrm{C}$ with $5 \% \mathrm{CO}_{2}$ in air and high humidity. From day 7 to 9 after fusion, embryo quality was recorded and some transferable blastocysts were transferred to recipients.

\section{Embryo transfer}

To assess the in vivo developmental potential of nuclear-transferred embryos, some blastocysts were transferred nonsurgically to the uterine horn of recipient cows. One or two embryos were transferred on day 7 or 8 after natural or prostaglandin $2 \alpha$-induced estrus. Pregnancy was diagnosed by ultrasound on day 35 .

\section{Microsatellite analyses}

In order to certify the genetic identity between the fetal fibroblast cell line and the cloned calf, genomic DNA was purified from calf peripheral blood cells and from one sample of the fetal fibroblast cell line as described by Sambrook et al. (13). To confirm the exclusion of the recipient cow as the cloned calf's mother, genomic DNA of the recipient was also purified from peripheral blood cells.

DNA samples were analyzed for 11 bovine microsatellite DNA regions (BM2113, TGLA122, BM1818, RM067, ETH10, INRA023, TGLA126, SPS115, ETH225, BM1824, and RM006). Briefly, two multiplex PCR assays were performed: multiplex 1 (ETH10, TGLA126, RM067, SPS115, INRA023, and ETH225) and multiplex 2 (RM006, TGLA122, BM1824, BM1818, and BM2113). Each PCR consisted of 10X AmpliTaq Gold PCR buffer (Applied Biosystems $^{\circledR}$, Foster City, CA, USA), $2.5 \mathrm{mM}$ $\mathrm{MgCl}_{2}, 2.5 \mathrm{mM}$ each dNTP, 10 ng DNA, 1 IU AmpliTaq Gold, 10 pmol of each primer
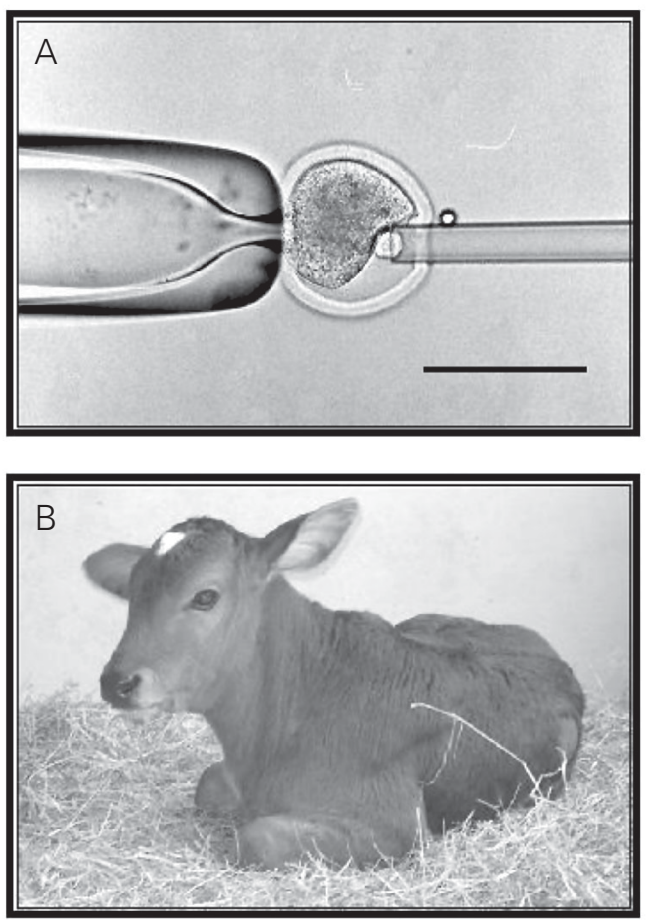

Figure 1. A, Reconstruction of an enucleated oocyte with a G0/ G1 fetal fibroblast. Bar $=120$ $\mu \mathrm{m}$. B, Cloned calf (1 month old and $51 \mathrm{~kg}$ ). 
(for each primer pair, one of them was labeled with fluorescent dye, 6-FAM, HEX and TAMRA, depending on the size of the expected amplicon, in order to permit electrophoretic analysis in a single run). DNA amplification was performed in a thermocycler (PTC 100 MJ Research ${ }^{\circledR}$, Waltham, MA, USA). After the first denaturing step at $95^{\circ} \mathrm{C}$ for $5 \mathrm{~min}$ followed by $85^{\circ} \mathrm{C}$ for $10 \mathrm{~min}$, 5 cycles of denaturing $\left(94^{\circ} \mathrm{C} / 1 \mathrm{~min}\right)$, annealing $\left(58^{\circ} \mathrm{C} / 30 \mathrm{~s}\right)$ and polymerization $\left(72^{\circ} \mathrm{C} / 30 \mathrm{~s}\right)$ and 26 cycles of denaturing $\left(94^{\circ} \mathrm{C} / 45 \mathrm{~s}\right)$, annealing $\left(58^{\circ} \mathrm{C} / 30 \mathrm{~s}\right)$ and polymerization $\left(72^{\circ} \mathrm{C} /\right.$ $30 \mathrm{~s}$ ) were performed. A last step at $72^{\circ} \mathrm{C}$ for 10 min was performed in order to guarantee the final extension of DNA molecules.

One microliter of each multiplex reaction was pooled and supplemented with 12 $\mu \mathrm{l}$ formamide and $1 \mu \mathrm{l}$ DNA molecular weight marker (ROX 500, Applied Biosystems ${ }^{\circledR}$ ), and loaded onto an automated DNA fragment analyzer (ABI Prism 310, Applied Biosystems $^{\circledR}$ ).

Of 664 oocytes selected for in vitro maturation, $444(66.9 \%)$ reached metaphase II and only $224(50.5 \%)$ were successfully enucleated.

The fusion rate of enucleated oocytes reconstructed with fetal fibroblasts and the in vitro developmental ability of these embryos were evaluated. Of 191 oocytes reconstituted by nuclear transfer using fetal fibroblasts, $83(43.5 \%)$ were fused and $24(28.9 \%)$

Table 1. Analysis of 11 bovine microsatellite regions in DNA samples from fetal fibroblasts, cloned calf and recipient cows.

\begin{tabular}{lccc}
\hline Locus/allele & Fetal fibroblast & Cloned calf & Recipient \\
\hline BM2113 & $129 / 135$ & $129 / 135$ & $123 / 131$ \\
TGLA122 & $145 / 154$ & $145 / 154$ & $138 / 138$ \\
BM1818 & $259 / 259$ & $259 / 259$ & $261 / 261$ \\
RM067 & $83 / 83$ & $83 / 83$ & $83 / 95$ \\
ETH10 & $211 / 211$ & $211 / 211$ & $207 / 219$ \\
INRA023 & $203 / 211$ & $203 / 211$ & $207 / 211$ \\
TGLA126 & $117 / 121$ & $117 / 121$ & $115 / 115$ \\
SPS115 & $243 / 245$ & $243 / 245$ & $241 / 245$ \\
ETH225 & $138 / 154$ & $138 / 154$ & $154 / 154$ \\
BM1824 & $177 / 179$ & $177 / 179$ & $177 / 181$ \\
RM006 & $106 / 112$ & $106 / 112$ & $112 / 118$ \\
& & &
\end{tabular}

developed to the blastocyst stage.

After transferring 18 blastocysts to 14 recipients, we confirmed pregnancy in five $(27.8 \%)$ on day 35 . Although some recipients had received two embryos, all five pregnancies consisted of only a single fetus. On day 90 , only three recipients $(16.7 \%)$ were pregnant. One pregnancy resulted in the birth of one male weighing $34 \mathrm{~kg}$ and apparently normal and healthy (Figure 1B). One recipient died of hydrallantois 2 months before term. The placenta was edematous and the umbilical vessels of the fetus were of wider diameter than expected for a neonate. One aborted fetus was recovered at 8 months of gestation. Some gross observations of the pathology of the aborted fetuses were subcutaneous edema and mandible malformation.

Genetic identity between the fibroblast cell line and cloned calf was determined by microsatellite analysis, which also permitted the exclusion of the recipient as the genetic mother of the cloned calf (Table 1).

Examination of the in vitro and in vivo development of the bovine nuclear-transferred embryos showed that the proportion of matured oocytes after 16-18 h of in vitro maturation was relatively low $(66.9 \%)$. The low maturation rate may have been due to the poor quality of the oocytes from the slaughterhouse and to the short time of in vitro maturation (16-18 h). However, at this time the enucleation rate is higher than after $24 \mathrm{~h}$ of maturation (Marques MG, Mello MRB and Visintin JA, unpublished results).

The stage of the donor cell cycle is a major factor in the success of nuclear transfer in mammals. Quiescent donor cells arrested in the G1 or G0 stage of the cell cycle have been used to produce cloned offspring (14). Serum starvation is often used as a donor cell treatment prior to nuclear transfer for arresting cells in this phase of the cycle. An acceptable rate of development to the blastocyst stage $(28.9 \%)$ was achieved with serum starvation of fetal fibroblast cultures, indicating that this treatment is beneficial for 
nuclear reprogramming. Zakhartchenko et al. (8), in a study of the effect of serum starvation on the efficiency of nuclear transfer using bovine fetal fibroblasts, also observed that the nuclei of starved fibroblasts supported in vitro development better than those of non-starved fibroblasts (39\% versus $20 \%$ ). Arat et al. (15), using genetically manipulated adult fibroblasts, obtained a lower in vitro development rate (11.4\%).

Studies on bovine nuclear transfer using blastomeres as the nucleus donors have shown a high incidence of pregnancy losses and also of placental abnormalities (8). Hill et al. (16) investigated the possible causes of high pregnancy losses in fetuses from embryos reconstructed with fetal and adult fibroblasts and observed that the gross vascularity of the placenta was much reduced and the maternal caruncles were small and underdeveloped. In our study, two of five established pregnancies were aborted before day 90. Among the re- maining three recipients, one male was delivered by Cesarean section on day 290 of gestation weighing $34 \mathrm{~kg}$. This calf is apparently normal and healthy. The placenta was collected and its morphological characteristics are currently under investigation. One recipient died of hydrallantois 2 months before term and one aborted fetus was recovered at 8 months of gestation.

The present study shows that bovine fetal fibroblasts can be used in nuclear transfer procedures resulting in acceptable rates of in vitro development and are also capable of supporting full development.

\section{Acknowledgments}

The authors thank LinkGen Biotecnologia Veterinária S/C, Araçatuba, SP, Brazil, for support with the microsatellite analysis and Panorama Farm for maintenance of the recipient cows.

\section{References}

1. Spemann H (1938). Embryonic Development and Induction. Hafner Publishing Company, New York, 210-211.

2. Campbell KHS, Loi P, Otaegui PJ \& Wilmut I (1996). Cell cycle coordination in embryo cloning by nuclear transfer. Reviews of Reproduction, 1: 40-46.

3. Cibelli JB, Stice SL, Golueke PJ, Kane JJ, Jerry J, Blackwell C, León FAP \& Robl JM (1998). Cloned transgenic calves produced from nonquiescent fetal fibroblasts. Science, 280: 1256-1258.

4. Wilmut I, Schnieke AE, McWhir J, Kink AJ \& Campbell KHS (1997). Viable offspring derived from fetal and adult mammalian cells. Nature, 385: 810-813.

5. Kato Y, Tani T, Sotomaru Y, Kurokawa K, Kato J, Doguchi $H$, Yasue $H$ \& Tsunoda $Y$ (1998). Eight calves cloned from somatic cells of a single adult. Science, 282: 2095-2098.

6. Wakayama T, Perry ACF, Zuccotti M, Johnson KR \& Yanagimachi R (1998). Full-term development of mice from enucleated oocytes injected with cumulus cell nuclei. Nature, 394: 369-374.

7. Wells DN, Misica PM \& Tervit HR (1999). Production of cloned calves following nuclear transfer with cultured adult mural granulosa cells. Biology of Reproduction, 60: 996-1005.

8. Zakhartchenko V, Durcova-Hills G, Stojkovic M, Schernthaner W, Prelle K, Steinborn R, Muller M, Brem G \& Wolf E (1999). Effects of serum starvation and re-cloning on the efficiency of nuclear transfer using bovine fetal fibroblasts. Journal of Reproduction and Fertility, 115: 325-331.

9. Kasinathan P, Knott JG, Moreira PN, Burnside AS, Jerry DJ \& Robl JM (2001). Effect of fibroblast donor cell age and cell cycle on development of bovine nuclear transfer embryo in vitro. Biology of
Reproduction, 64: 1487-1493

10. Uhm SJ, Kim NH, Kim T, Chung HM, Chung KH, Lee HT \& Chung KS (2000). Expression of enhanced green fluorescent protein (EGFP) and neomycin resistant $\left(\mathrm{Neo}^{R}\right)$ genes in porcine embryos following nuclear transfer with porcine fetal fibroblasts transfected by retrovirus vector. Molecular Reproduction and Development, 57: 331-337.

11. Wells DN, Misica PM, McMillan WH \& Tervit HR (1998). Production of cloned bovine fetuses following nuclear transfer using cells from a fetal fibroblast cell line. Theriogenology, 49: 330 (Abstract).

12. Vignon $X$, Chesne $P$, LeBourhis D, Heyman $Y$ \& Renard JP (1998). Developmental potential of bovine embryos reconstituted with somatic nuclei from cultured skin and muscle fetal cells. Theriogenology, 49: 392 (Abstract).

13. Sambrook J, Fritsch EF \& Maniatis T (1989). Molecular Cloning: A Laboratory Manual. Vols. 1, 2, and 3. Cold Spring Harbor Laboratory Press, New York.

14. Gibbons J, Arat S, Rzucidlo J, Kazuchika M, Waltenburg R, Respess D, Venable A \& Stice S (2002). Enhanced survivability of cloned calves derived from roscovitine-treated adult somatic cells. Biology of Reproduction, 66: 895-900.

15. Arat S, Gibbons JR, Rzucidlo SJ \& Stice SL (2002). In vitro development of transgenic bovine embryos derived from nuclear transfer of transfected adult fibroblast cells. Theriogenology, 57: 394 (Abstract).

16. Hill JR, Long CR, Looney CR, Winger QA, Spencer TE, Bazer FW, Burghardt RC \& Westhusin ME (2000). Placental abnormalities in first trimester somatic cell cloned fetuses. Theriogenology, 53: 218 (Abstract). 